\title{
A Culture-Based ID of Micromycetes on the Wing Membranes of Greater Mouse-Eared Bats (Myotis myotis) from the "Nietoperek" Site (Poland)
}

\author{
Rafał Ogórek ${ }^{1, *(1)}$, Klaudia Kurczaba ${ }^{1}$, Magdalena Cal ${ }^{1}$, Grzegorz Apoznański ${ }^{2}$ and \\ Tomasz Kokurewicz ${ }^{2}$ (D) \\ 1 Department of Mycology and Genetics, Institute of Genetics and Microbiology, University of Wrocław, \\ Przybyszewskiego Street 63-77, 51-148 Wrocław, Poland; 289395@uwr.edu.pl (K.K.); \\ magdalena.cal@uwr.edu.pl (M.C.) \\ 2 Department of Vertebrate Ecology and Paleontology, Institute of Biology, Wrocław University of \\ Environmental and Life Sciences, Kożuchowska Street 5b, 51-631 Wrocław, Poland; \\ apoznanski.grzegorz@gmail.com (G.A.); tomasz.kokurewicz@upwr.edu.pl (T.K.) \\ * Correspondence: rafal.ogorek@uwr.edu.pl; Tel.:+48-71-375-6291; Fax: +48-71-325-2151
}

Received: 15 June 2020; Accepted: 30 July 2020; Published: 3 August 2020

Simple Summary: This study reports the colonization by fungi of the wing membranes of the female greater mouse-eared bat (Myotis myotis) during spring emergence from the "Nietoperek" underground hibernation site. Overall, we isolated 17 different fungal species and the most commonly isolated was Penicillium chrysogenum - the cosmopolitan species. Some fungal species may be pathogens of mammals, including bats. However, taking into account habitat preferences and the life cycle of bats, it can be assumed that some fungi were accidentally obtained from the surface of vegetation during early spring activity. Therefore, in the near future, we want to study the mycobiota of other bat species because they could be pathogens or part of the normal microbiome.

Abstract: Bats play important functions in ecosystems and many of them are threatened with extinction. Thus, the monitoring of the health status and prevention of diseases seem to be important aspects of welfare and conservation of these mammals. The main goal of the study was the identification of culturable fungal species colonizing the wing membranes of female greater mouse-eared bat (Myotis myotis) during spring emergence from the "Nietoperek" underground hibernation site by the use of genetic and phenotypic analyses. The study site is situated in Western Poland $\left(52^{\circ} 25^{\prime} \mathrm{N}\right.$, $15^{\circ} 32^{\prime} \mathrm{E}$ ) and is ranked within the top 10 largest hibernation sites in the European Union. The number of hibernating bats in the winter exceeds 39,000 individuals of 12 species, with M. myotis being the most common one. The wing membranes of $M$. myotis were sampled using sterile swabs wetted in physiological saline $(0.85 \% \mathrm{NaCl})$. Potato dextrose agar (PDA) plates were incubated in the dark at 8 , 24 and $36 \pm 1{ }^{\circ} \mathrm{C}$ for 3 up to 42 days. All fungi isolated from the surface of wing membranes were assigned to 17 distinct fungal isolates belonging to 17 fungal species. Penicillium chrysogenum was the most frequently isolated species. Some of these fungal species might have a pathogenic potential for bats and other mammals. However, taking into account habitat preferences and the life cycle of bats, it can be assumed that some fungi were accidentally obtained from the surface of vegetation during early spring activity. Moreover, Pseudogymnoascus destructans (Pd) - the causative agent of the White Nose Syndrome (WNS) — was not found during testing, despite it was found very often in M. myotis during previous studies in this same location.

Keywords: fungi; Myotis; wing membranes; hibernation; “Nietoperek" bat reserve 


\section{Introduction}

Bats (Chiroptera), inhabiting all continents except Antarctica, with more than 1400 species described so far, are the second most numerous order among all mammals [1,2]. Most species are insectivorous and serve an important role in the reduction of insect abundance, including agricultural and forest pests, and species harmful for humans such as mosquitoes (Culicidae) and biting midges (Simuliidae and Ceratopogonidae) [3], although in the tropics many bats developed different feeding strategies and serve as plant pollinators and seed dispersers [4]. Almost half of bats are vulnerable (VU), considered endangered (EN), near threatened (NT) or critically endangered (CR) and are listed in the IUCN Red List of Endangered Species [5,6].

In autumn, insectivorous bats inhabiting temperate zones are looking for overwintering refugia as a place of hibernation to survive adverse environmental conditions i.e., temperature drop and reduced insect availability. Selection of suitable hibernation sites, such as caves and mines, is crucial for overwinter survival [7]. Bat hibernacula need to meet specific microclimatic conditions that can sustain the hibernation cycle of bats. Some species are declining the average hibernation temperature in course of winter season to slow down the use of energy reserves accumulated in fat [8]. At the "Nietoperek" Natura 2000 site, the median temperature is $8.7^{\circ} \mathrm{C},\left(\min -\max 6.1-9.9^{\circ} \mathrm{C}\right)$ and humidity varies between $77.5-100.0 \%$ [9]. It should be mentioned that temperature and humidity are among the most important factors affecting the survival of fungi in the environment $[10,11]$. An additional factor in determining the occurrence of fungi in underground sites are the neighboring external environment, especially local flora, the geographical location, and availability of organic matter [12-14]. However, it should be mentioned that low annual temperature as well as low humidity increased prevalence of microfungi on bat ectoparasites [15].

Furthermore, the organic matter is scarce in the underground, therefore, bats serve an important role for fungi survival as hosts and producers of organic waste, such as guano and dead individuals [9]. Additionally, their annual visits in the underground system sustain a stable source for external spores enriching fungi flora $[9,13]$. Simultaneously, during hibernation season, bats are periodically changing locations within the hibernaculum [16]. Towards the end of the winter season, some species, such as the greater mouse-eared bat (Myotis myotis), tend to form large clusters creating an opportunity for fungi to spread between individuals [9].

In Europe, the highest species diversity can be observed in the Mediterranean region however, due to mild winters and the overall rise in annual temperature, many species have begun to expand their ranges to the north [17-22]. The range expansion may lead to transmission of microorganisms previously unobserved in colder regions of Europe including fungi with pathogenic potential [23-27]. Despite the common occurrence of bats in Europe, many aspects of biology and ecology remain insufficiently studied. One concerns the characterization of the fungal community on the wing membranes of Central-European bats such as M. myotis [28,29]. Therefore, the number of bats and factors determining their health (including microorganisms) should be monitored in order to protect these endangered mammals [30,31].

Most of the mycological studies of the fur and skin of bats are related to their hibernation sites. For example, Johnson et al. [32] isolated the psychrophilic and psychrotolerant fungal flora of the wing membranes of hibernating bats in USA (Illinois and Indiana) such as Indiana bat (Myotis sodalis), tricolored bat (Pipistrellus subflavus), and northern myotis (Myotis septentrionalis). In turn, Vanderwolf et al. [25,33] and Malloch et al. [34] studied fungi associated with hibernating P. subflavus and little brown bat (Myotis lucifugus) and M. septentrionalis in Canada. However, most research on bat specific external fungi from temperate regions revolves around Pseudogymnoascus destructans (Pd) [35]. Pd causes the disease known as the White Nose Syndrome (WNS), which is a recently emerged wildlife disease that has decimated bats in North America [36-41]. Currently, the occurrence of Pd has also been found in fifteen European countries (Austria, Belgium, Switzerland, Czech Republic, Germany, Denmark, Estonia, France, Hungary, Netherlands, Poland, Romania, Slovakia, Turkey and Ukraine), but the mass deaths of the bats was not observed $[9,20,23,24]$. 
Little is known about external fungi colonizing the wing membranes of $M$. myotis during spring emergence from underground hibernation sites. The main goal of this study was to identify culturable fungal species from wing membranes of female M. myotis bats using genetic and phenotypic analysis, as the first step toward of monitoring bat health.

\section{Materials and Methods}

\subsection{Study Area}

Miedzyrzecz Fortified Front (Ostwall or Festungsfront im Oder-Warthe Bogen) situated in Western Poland $\left(52^{\circ} 25^{\prime} \mathrm{N}, 15^{\circ} 32^{\prime} \mathrm{E}\right)$ is a massive subterrain fortification complex built by the Germans in 1934-1944. Its Central Sector "Wysoka" (Zentralabschnitt or Abschnitt Hochwalde), where the observations were carried out, includes a system of concrete tunnels with a total length of approximately $32 \mathrm{~km}$ situated 20-30 $\mathrm{m}$ in the underground. The axis of the underground system called the "main road" is connected to the smaller side corridors leading to aboveground bunkers (Panzerwerk), that are access points for bats into the underground system. The "Nietoperek" bat reserve situated in Central Sector "Wysoka" is ranked among the top 10 largest hibernation sites in the European Union. The number of hibernating bats exceeds 39,000 individuals in some years. In 2007 the whole underground system with the surrounding surface area of 7377.37 ha became protected as Natura 2000 site "Nietoperek" (area code: PLH080003). Out of 12 bat species found hibernating in the "Nietoperek", four are mentioned in Annex II of the EU Habitat Directive. More detailed descriptions of the "Nietoperek" bat reserve is given in our previous publications [9,42,43].

\subsection{Sample Collection}

On 10th April 2016 from 21:28 and 23:31 the bats emerging from the underground fortifications of the "Nietoperek" bat reserve through the aboveground bunker Pz.W. 766 were captured by the use of two 6-m-long monofilament mist-nets (Ecotone, Poland) erected on 2.5-m-high poles (Figure 1). Using latex gloves, we determined the sex and the species using the identification key by Dietz and von Helversen [44]. Then, we collected swabs from bats wing membranes. The whole procedure lasted up to $15 \mathrm{~min}$, after which the bats were released in the place of capture. Out of 18 individuals belonging to 5 species being caught, we selected the homogenous and largest sample consisting of 12 females of the greater mouse-eared bat (M. myotis) for analyses.

We decided to select $M$. myotis for our study because it migrates long distances between summer and winter roosts which can enhance contacts to other hosts, vectors and microorganisms as well as the microbial diversity compared to sedentary species of bats. The longest migrations of M. myotis from the "Nietoperek" bat reserve recorded so far exceeded $227 \mathrm{~km}$ [45] and cover large parts of Eastern Germany and Western Poland. Additionally, our studied species is listed in an Annex II Council Directive 92/43/EEC which places it under special protection in the European Union.

The flight membranes of M. myotis were sampled using sterile swabs wetted in physiological saline $(0.85 \% \mathrm{NaCl})$ and stored in transport tubes (plastic applicator and viscose swab of 15 - $\mathrm{cm}$ length). Every bat was sampled with two swabs from the inner surface of the flight membranes (one swab for one wing): plagiopatagium and dactylopatagia. Caution was taken to avoid cross-contamination by changing latex gloves between bats sampled. The samples were transported to the laboratory and were stored in the cold room $\left(10 \pm 0.5^{\circ} \mathrm{C}\right)$ until mycological analysis, which was carried out within 4 days.

The observations were carried out under the license nr. WPN-I.6205.21.2016.AI provided by Regional Directorate for Environmental Protection in Gorzów Wielkopolski. 


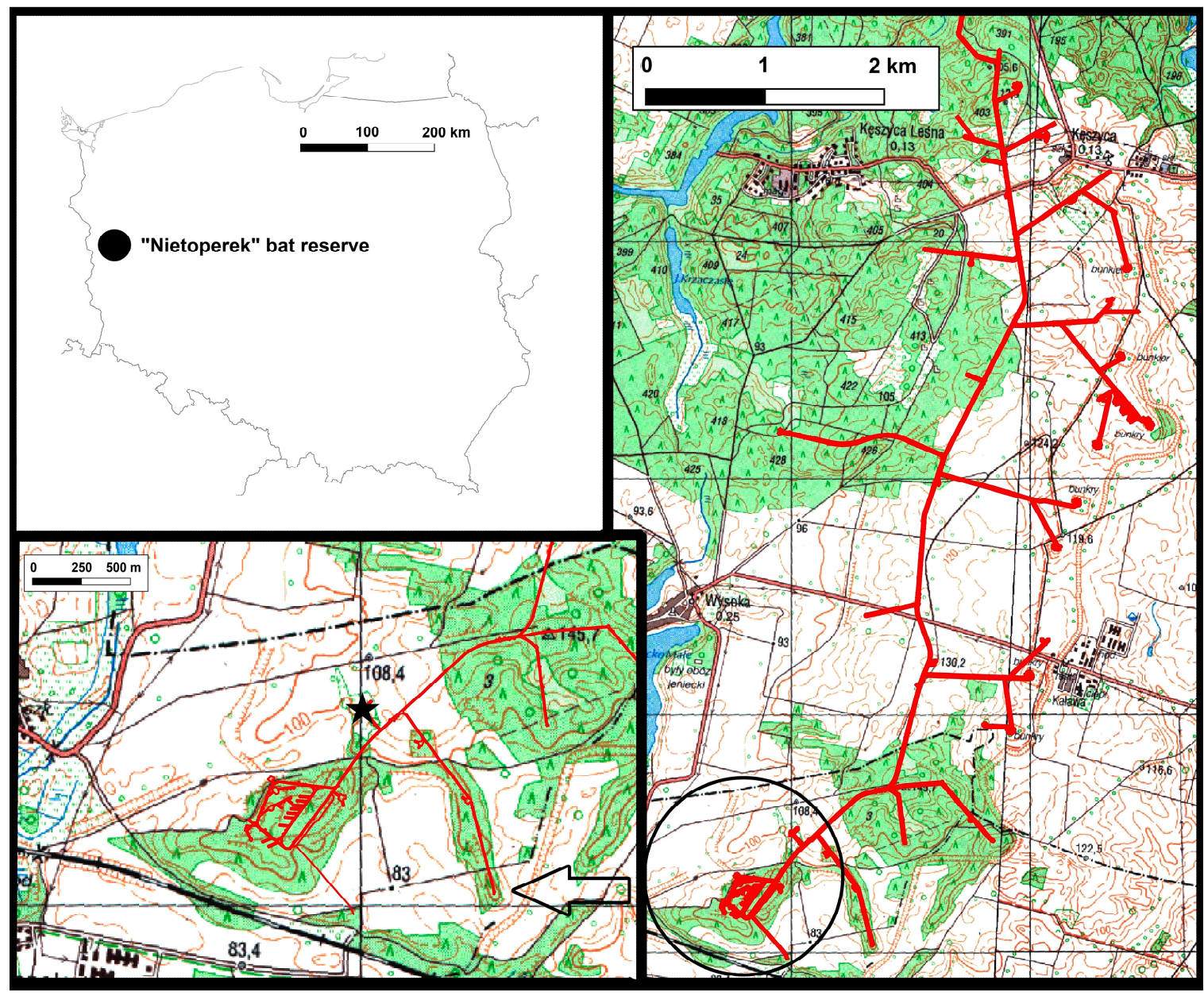

Figure 1. Underground corridors of Central Sector of Międzyrzecz Fortified Front in Western Poland. Netting place in the entrance to bunker Pz.W. 766 is marked by a black asterisk.

\subsection{Isolation of Fungi from Samples}

The isolation of fungi was performed using conventional culture methods. The swabs from both wing membranes of one bat were put together into one 50-mL Erlenmeyer flask containing $10 \mathrm{~mL}$ of sterile distilled water, and they were shaken for $20 \mathrm{~min}$. Then, the biological material was plated into potato dextrose agar plates (PDA, BioMaxima, Poland) by using serial dilution isolation method. The plates were incubated in the dark at 8,24 and $36 \pm 1{ }^{\circ} \mathrm{C}$ for 3 up to 42 days $\left(8{ }^{\circ} \mathrm{C}\right.$ corresponds to the temperature of the hibernation place and for psychrophilic and psychrotolerant fungi; $24^{\circ} \mathrm{C}$ is the optimal growth temperature of the majority of fungal species; $36^{\circ} \mathrm{C}$ is the temperature oscillating with respect to the body of mammals and thermophilic species). After incubation, fungi were purified by the single spore method and were subcultured on PDA slants for morphological and molecular identification.

\subsection{Identification of Fungi}

The preliminary identification of isolated fungi was based on macro- and microscopic evaluation on the following media: Czapek Yeast Autolysate Agar $\left(\mathrm{CYA}, 30.0 \mathrm{~g} \cdot \mathrm{L}^{-1}\right.$ sucrose, $15 \mathrm{~g} \cdot \mathrm{L}^{-1}$ agar, $5.0 \mathrm{~g} \cdot \mathrm{L}^{-1}$ yeast extract, $3.0 \mathrm{~g} \cdot \mathrm{L}^{-1} \mathrm{NaNO}_{3}, 1.0 \mathrm{~g} \cdot \mathrm{L}^{-1} \mathrm{~K}_{2} \mathrm{HPO}_{4}, 0.5 \mathrm{~g} \cdot \mathrm{L}^{-1} \mathrm{KCl}, 0.5 \mathrm{~g} \cdot \mathrm{L}^{-1} \mathrm{MgSO}_{4} \cdot 7 \mathrm{H}_{2} \mathrm{O}, 0.01 \mathrm{~g} \cdot \mathrm{L}^{-1}$ $\left.\mathrm{FeSO}_{4} \cdot 7 \mathrm{H}_{2} \mathrm{O}\right)$, Czapek-Dox agar (1.2\% agar, BioMaxima, Poland), malt extract agar (MEA, BioMaxima, Lublin, Poland) and PDA. Plates were incubated in the dark at 15 and $20 \pm 1{ }^{\circ} \mathrm{C}$ for $7-42$ days. The fungi were identified according to available monographs [46-58]. Additionally, the phenotypes of some fungi were also compared with strains from R. Ogórek's collection (Department of Mycology 
and Genetics, Institute of Genetics and Microbiology, University of Wrocław, Wrocław, Poland), which were identified using phenotypic and molecular studies, based on their internal transcribed spacer (ITS) region sequences deposited in the National Center for Biotechnology Information (NCBI, Bethesda, Rockville, MD, USA). Microscopic slides were dyed with LPCB (lactophenol cotton blue, Sigma-Aldrich). Microscopic photographs were taken with Axio Image.M1 (Zeiss, Göttingen, Germany) and macroscopic with Nikon Coolpix S3700.

To confirm species affiliation, fungal ITS region was sequenced. DNA was extracted from 21-day-old cultures on PDA medium by using Bead-Beat Micro AX Gravity (A\&A Biotechnology, Gdańsk, Poland) according to the manufacturer's instructions. Fungal rDNA was amplified using primers ITS1 (5'-TCCGTAGGTGAACCTGCGG-3') and ITS4 (5'-TCCTCCGCTTATTGATATGC-3') [59]. PCR was performed in a T100 Thermal Cycler (Bio-Rad, Berkeley, CA, USA), according to Ogórek et al. [60]. The PCR products were verified by electrophoretic separation on a 1.2\% agarose gel and, subsequently, purified using Clean-UP (A\&A Biotechnology, Gdańsk, Poland) and sequenced by the sequencing service at Macrogen Europe (Netherlands, http://dna.macrogen.com/eng/).

\subsection{Data Analyses}

The Raw sequence reads were analyzed using the BioEdit Sequence Alignment Editor (http://www.mbio.ncsu.edu/bioedit/bioedit.html) and compared with those deposited in the GenBank of the National Center for Biotechnology Information (NCBI, Bethesda, MD, USA) using the BLAST algorithm (http://www.ncbi.nlm.nih.gov/). Generated rDNA sequences were submitted to NCBI GenBank under accession numbers MN654343-MN654359.

\section{Results}

All fungi obtained from swabs were assigned to 17 distinct fungal isolates. These fungi were classified using a combination of phenotypic and molecular methods into two different phyla, 10 orders, 13 genera, including 17 different species, i.e., Arachniotus ruber, Gymnascella aurantiacan and Arthroderma quadrifidum (Ascomycota, Onygenales), Aspergillus fumigatus, A. jensenii, Penicillium brevistipitatum, P. chrysogenum, P. citreonigrum and P. coprophilum, (Ascomycota, Eurotiales), Bartalinia robillardoides (Ascomycota, Amphisphaeriales), Chaetomium globosum (Ascomycota, Sordariales), Cladosporium sphaerospermum (Ascomycota, Capnodiales), Cylindrobasidium laeve (Basidiomycota, Agaricales), Cystobasidium ongulense (Basidiomycota, Cystobasidiales), Pararamichloridium caricicola (Ascomycota, Pararamichloridiales), Phialemonium atrogriseum (Ascomycota, Cephalothecales) and Scopulariopsis brevicaulis (Ascomycota, Microascales). All fungi found in this study received internal isolate numbers from UWR_152 to UWR_167, and their ITS nucleotide sequences were submitted to GenBank under accession numbers from MN654343.1 to MN654359.1 (Table 1).

Overall, the species composition of the fungal communities inhabiting the wing membranes of female greater mouse-eared bats was different between individuals. The wing membranes of individual bats tested were colonized with 4 to 7 fungal species (Table 1). To a large extent, the species composition of fungi also depended on the incubation temperature of Petri dishes with biological material. Most fungal species $(n=16)$ were isolated from the tested samples using an incubation temperature at $24 \pm 1^{\circ} \mathrm{C}$, and least species $(\mathrm{n}=3)$ at $36 \pm 1^{\circ} \mathrm{C}$. Fungal species such as $A$. ruber, A. jensenii, B. robillardoides, C. sphaerospermum, C. laeve, P. caricicola, P. brevistipitatum and P. citreonigrum were cultured only at $24 \pm 1^{\circ} \mathrm{C}$. In turn, G. aurantiaca was isolated only at $8 \pm 1{ }^{\circ} \mathrm{C}$ (Table 1$)$. 
Table 1. Diversity of fungal species isolated from the wing membranes of 12 female greater mouse-eared bats (Myotis myotis).

\begin{tabular}{|c|c|c|c|c|c|c|c|c|c|c|c|c|c|c|}
\hline \multicolumn{3}{|c|}{ Micromycetes } & \multicolumn{12}{|c|}{ Myotis Myotis +} \\
\hline Fungal Species & $\begin{array}{c}\text { Isolate } \\
\text { Number }\end{array}$ & $\begin{array}{l}\text { Accession No. in } \\
\text { NCBI Database }\end{array}$ & 1 & 2 & 3 & 4 & 5 & 6 & 7 & 8 & 9 & 10 & 11 & 12 \\
\hline Arachniotus ruber & UWR_152 & MN654344.1 & & & & & $x^{2}$ & & $x^{2}$ & & $x^{2}$ & & & $x^{2}$ \\
\hline $\begin{array}{l}\text { Arthroderma } \\
\text { quadrifidum }\end{array}$ & UWR_153 & MN654345.1 & & $x^{2}$ & & & $x^{1}$ & & $x^{1}$ & & & $x^{2}$ & $x^{2}$ & \\
\hline Aspergillus fumigatus & UWR_154 & MN654346.1 & $x^{3}$ & $x^{3}$ & $x^{3}$ & & $x^{2,3}$ & & & $x^{3}$ & $x^{3}$ & & & \\
\hline Aspergillus jensenii & UWR_155 & MN654347.1 & & & & & & & & & & & $x^{2}$ & \\
\hline $\begin{array}{l}\text { Bartalinia } \\
\text { robillardoides }\end{array}$ & UWR_156 & MN654348.1 & & & & $x^{2}$ & & $x^{2}$ & & & & & & $x^{2}$ \\
\hline Chaetomium globosum & UWR_157 & MN654349.1 & $x^{1}$ & & & & & & & & & $x^{2}$ & $x^{2}$ & \\
\hline $\begin{array}{l}\text { Cladosporium } \\
\text { sphaerospermum }\end{array}$ & UWR_158 & MN654350.1 & & $x^{2}$ & & $x^{2}$ & & & & $x^{2}$ & $x^{2}$ & $x^{2}$ & & \\
\hline Cylindrobasidium laeve & UWR_159 & MN654351.1 & $x^{2}$ & $x^{2}$ & & & & & & $x^{2}$ & & & & $x^{2}$ \\
\hline $\begin{array}{l}\text { Cystobasidium } \\
\text { ongulense }\end{array}$ & UWR_160 & MN654352.1 & & & $x^{1,2}$ & & & & $x^{1,2}$ & & & & & \\
\hline $\begin{array}{c}\text { Gymnascella } \\
\text { aurantiaca }\end{array}$ & UWR_151 & MN654343.1 & & & $x^{1}$ & $x^{1}$ & & & & $x^{1}$ & & & $x^{1}$ & \\
\hline $\begin{array}{l}\text { Pararamichloridium } \\
\text { caricicola }\end{array}$ & UWR_161 & MN654353.1 & & & $x^{2}$ & & & & & & & & & \\
\hline $\begin{array}{c}\text { Penicillium } \\
\text { brevistipitatum }\end{array}$ & UWR_162 & MN654354.1 & & & $x^{2}$ & & & $x^{2}$ & & & $x^{2}$ & & $x^{2}$ & $x^{2}$ \\
\hline $\begin{array}{l}\text { Penicillium } \\
\text { chrysogenum }\end{array}$ & UWR_163 & MN654355.1 & $x^{3}$ & & & $x^{2}$ & $x^{2}$ & & $x^{2}$ & $x^{3}$ & & $x^{2}$ & $x^{2}$ & $x^{2}$ \\
\hline $\begin{array}{l}\text { Penicillium } \\
\text { citreonigrum }\end{array}$ & UWR_164 & MN654356.1 & & & $x^{2}$ & & & $x^{2}$ & & & & $x^{2}$ & & \\
\hline $\begin{array}{l}\text { Penicillium } \\
\text { coprophilum }\end{array}$ & UWR_165 & MN654357.1 & $x^{1,2}$ & & & & & & & & & & & $x^{2}$ \\
\hline $\begin{array}{l}\text { Phialemonium } \\
\text { atrogriseum }\end{array}$ & UWR_166 & MN654358.1 & & $x^{2}$ & & $x^{1,2}$ & & & & $x^{2}$ & $x^{2}$ & & & \\
\hline $\begin{array}{l}\text { Scopulariopsis } \\
\text { brevicaulis }\end{array}$ & UWR_167 & MN654359.1 & $x^{3}$ & & & $x^{1,2}$ & & $\mathrm{x}^{1}$ & $\mathrm{x}^{1}$ & & & & $x^{1}$ & \\
\hline
\end{tabular}

" $\mathrm{x}$ " indicates that the fungus was cultured from the samples, ${ }^{1}$ fungi cultured at $8 \pm 1{ }^{\circ} \mathrm{C},{ }^{2}$ fungi cultured at $24 \pm 1{ }^{\circ} \mathrm{C},{ }^{3}$ fungi cultured at $36 \pm 1{ }^{\circ} \mathrm{C}$. 
Aspergillus jensenii and P. caricicola were less cultured in the study, and only from one greater mouse-eared bat. Consequently, each of these species accounted for $1.5 \%$ of all cultured fungi from all incubation temperatures (Figure 2). On the other hand, the most frequently isolated species from the wing membranes was P. chrysogenum (Figures 2 and 3). This fungus constituted 12.3\% of all isolated species from all incubation temperatures, and it was isolated from 8 individuals out of 12 tested bats (Figure 2). Color of its colonies ranged from deep white (Czapek-Dox agar) to green (PDA), usually folded center, with broad white margin during the growing period (especially PDA) and in age with overgrowth of white or yellow hyphae (YPG, MEA). The pigmentation on the reverse of the culture media was yellow, with color diffusing somewhat (CYA, MEA, PDA). Penicillium chrysogenum formed characteristic microscopic structures such as rough stipes, branches, ramus and metulae (Figure 3).

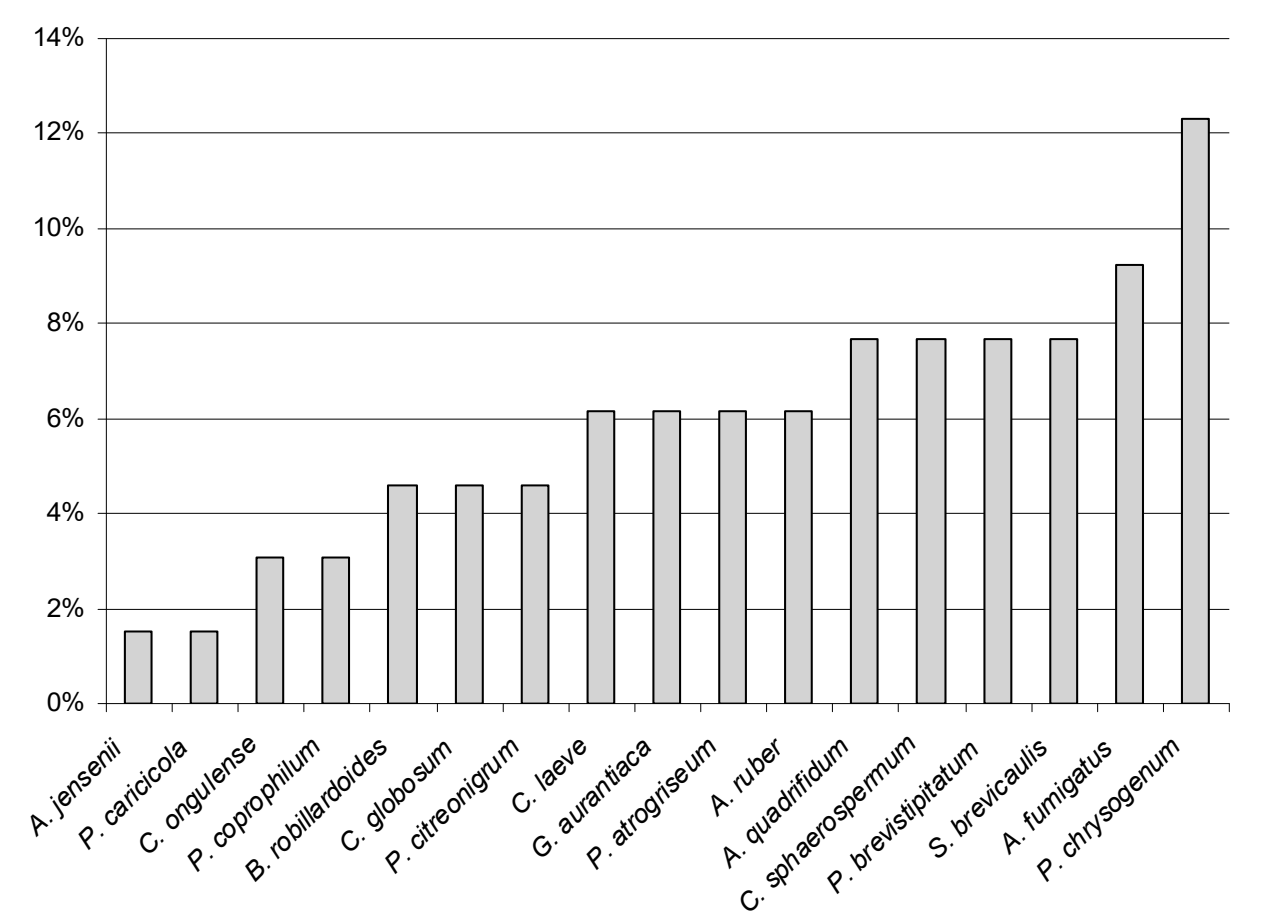

Figure 2. The percentage of which each species was isolated from the wing membranes of 12 female greater mouse-eared bats (Myotis myotis) contributed to the total from all incubation temperatures. 

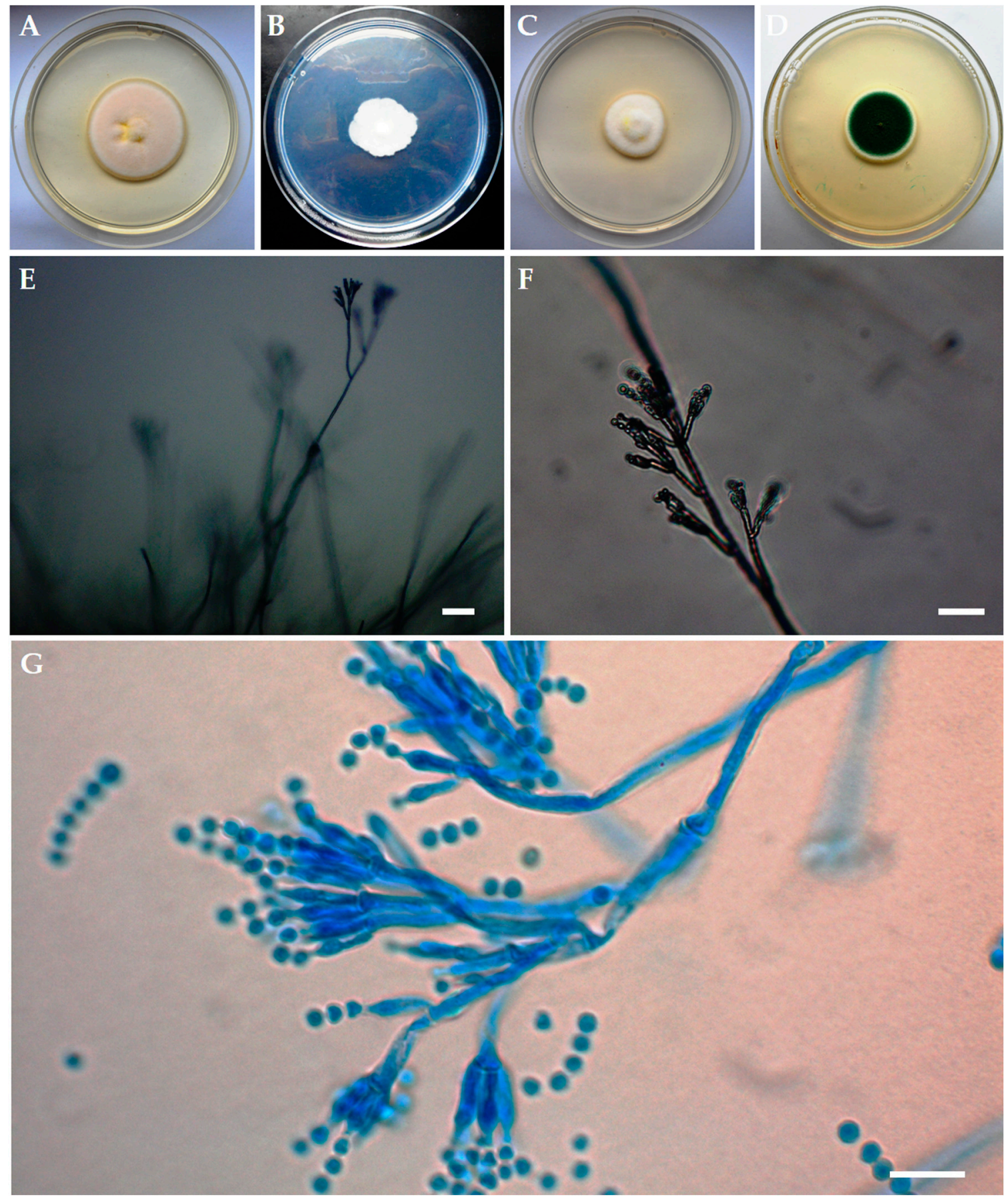

Figure 3. Macroscopic observations of 7-day-old Penicillium chrysogenum (A). CYA, (B). Czapek-Dox agar, (C). MEA, and (D). PDA and microscopic observations of morphological structures of 2-week-old P. chrysogenum (E,F). Petri dish cultures under the optical microscope with natural arrangement: stipe, branches, ramus, metulae, phialides, conidia, (G). Microscopic slide dyed with lactophenol cotton blue: rough branches, ramus and metulae, phialides, conidia) isolated most frequently from the wing membranes of female greater mouse-eared bats (Myotis myotis). The size of stipes ranged from 2.5-4 $\mu \mathrm{m}$, and of phialides ampuliform with a reduced neck from 7-10 to 2-2.5 $\mu \mathrm{m}$. Conidia were elliptical to subglobose, 3-4 in $\mu \mathrm{m}$ long axis, and smooth. Scale bars: $50 \mu \mathrm{m}(\mathbf{E}), 20 \mu \mathrm{m}(\mathbf{F}), 10 \mu \mathrm{m}(\mathbf{G}, \mathbf{H})$.

\section{Discussions}

It is well known that environmental stress is a major determinant in the evolution of living organisms. Therefore, considering the specific conditions prevailing in underground ecosystems as 
well as the specific physiology and behavior of hibernating bats, these microorganisms have likely adapted and tolerate adverse living conditions [60-63]. The underground will be mainly a place of occurrence of psychrotolerant fungi because they have better nutritional adaptability compare to psychrophilic fungi or due to horizontal gene transfer from mesophiles [64-66]. Thus, bats can be a source of such fungi, which is also illustrated by the results of our research. Moreover, the increase in temperature in underground ecosystems contributes, among other factors, to changes in the fungal communities inhabiting them and may lead to the emergence of new, previously unknown, fungi of mammals, birds and humans [67-71].

In our study, we used PDA because this medium demonstrates comparable efficacy as Sabouraud agar which is most suitable for isolation of a large spectrum of fungal species from biological samples [72,73]. In addition, we used three incubation temperatures $\left(8,24\right.$ and $\left.36 \pm 1{ }^{\circ} \mathrm{C}\right)$ for fungal isolations from the samples. In general, most fungi are cultivatable at "room temperature" from 20 to $25^{\circ} \mathrm{C}$. However, psychrophilic and psychrotolerant fungi, e.g., Pd grow better in lower temperatures (12.5 to $15.8{ }^{\circ} \mathrm{C}$ for its optimal growth) and these temperatures also correspond to the hibernation place [74]. On the other hand, $36^{\circ} \mathrm{C}$ is the temperature oscillating with respect to the body of mammals and thermophilic species [75]. Therefore, we use different temperatures to obtain a broader species spectrum of fungi as well as in the biological context.

Our study allowed us to identify 17 species from two different phyla. Ascomycota being the most numerous with 15 species (88.2\%) and Basidiomycota represented by two species (17.8\%). According to our knowledge, there are currently no studies on fungi inhabiting the wing membranes of females M. myotis during spring emergence from underground hibernation sites. Nevertheless, other researchers confirm that fungi belonging to Ascomycota phylum dominate on wing membranes of bats (M. sodalis, P. subflavus, M. septentrionalis and M. lucifugus) hibernating in underground sites [25,32,33]. However, we did not find the fungal species (Pd) on the wing membranes of female M. myotis during spring emergence from the "Nietoperek" underground hibernation site. These are unexpected results, because the presence of Pd has been reported in M. myotis in every study carried in the "Nietoperek" so far [9,76-78]. We think that our sampling targeting bats exiting the bunker either destroyed Pd as the bat body's temperature becomes elevated, or decreases the number and/or viability of Pd, which confirms other reports on this subject $[79,80]$. Because the limit temperature for $\mathrm{Pd}$ growth is $19.8{ }^{\circ} \mathrm{C}[74]$ and usually, during flight, the core body temperature in flying bats may range from $36.9^{\circ} \mathrm{C}$ up to $42.1^{\circ} \mathrm{C}[81,82]$. Another reason for the lack of Pd may be the limited number of samples that resulted from permits. This is due to the fact that this species in Poland is strictly protected and requires active protection [83]. Therefore, mycological studies of wintering bats and those flying from underground sites are an important element in the protection of these mammals [5].

The effects of fungi from this study on bat health is unknown. Therefore, we discuss the harmfulness of some of them in the context of people. Additionally, most of M. myotis breeding colonies in Poland occur in close proximity to people during the summer, hiding in large attics, church lofts and other buildings [84]. Currently, in Poland, only two breeding colonies use partially underground facilities as breeding places. These are the Studnisko cave in the Sokole Góry nature reserve and the underground fortifications of the "Nietoperek" bat reserve [85,86].

According to Johnson et al. [32] fungi belonging to the Penicillium genus accounted for about $13 \%$ of all the strains isolated from hibernating bats. This corresponds well which our results, as we confirmed 4 species from this genus $P$. brevistipitatum (found on 5 bats), P. chrysogenum ( 8 bats), P. citreonigrum (3 bats) P. coprophilum (2 bats). Each one of the tested animals had at least one Penicillium species present. The most numerous among them was $P$. chrysogenym, which constituted for $12.3 \%$ of all isolated species. This fungal species is commonly recovered in subterranean environments [10-12]; however, representing a family pose a potential health hazard, as Penicillium airborne, asexual spores are strong human allergens. These fungi are significantly related to an increased incidence of sick building syndrome (SBS) [87]. In specific circumstances, Penicillium spp. can pose a serious threat to immunocompromised humans, for example, suffering from AIDS or recovering after transplantations 
treated with immunosuppressant drugs. For example, P. marneffei has been well studied as a cause of severe mycosis in HIV-infected individuals, and P. chrysogenum was already reported as the first case of invasive pulmonary mycosis in a lung transplant recipient [88].

In our study, two fungal species belonged to Aspergillus (A. fumigatus and A. jensenii). Aspergillus may cause severe skin tineas and human aspergillosis. Furthermore, over the last few decades, filamentous fungi (or moulds) have emerged as a major cause of life-threatening infections in immunocompromised patients $[89,90]$. Aspergillus fungal spores are commonly found in indoor and outdoor air, including underground ecosystem, and they are also associated with SBS [10-12,87,91]. Aspergillus fumigatus is probably the "most dangerous" member of Aspergillus genus regarding health, this species being classified in risk group 2 regarding pathogen fungi [92].

Scopulariopsis brevicaulis is also an interesting species which was cultured during our study. Uusually, it occurs in soil or as a mould on decaying organic matter. However, this species is producing keratinases, proteolytic enzymes, capable of protein degradation. This fungus can cause onychomycosis, keratitis, otomycosis, invasive sinusitis, and prosthetic valve endocarditis. Treatment of Scopulariopsis infections is difficult as this genus displays high resistance to a broad spectrum of antifungal agents [93,94].

The Bartaliniaceae family was described by Tassi in 1990, and members of the genus have frequently been isolated from the leaves, stems of medicinal plants, or dead aerial spines of Rosa canina L. [95,96]. Bartalinia spp. is known to produce bioactive compounds eradicating pathogenic bacteria, fungi, and nematodes [97]. Bartalinia robillardoides, found on three out of 12 sampled bats is among our most interesting findings as it has been reported to produce taxol, an anticancer drug [98]. In turn, C. globosum is a well-known mesophilic mould and it was also isolated during our study. This fungal species is found in a wide range of habitats from forests to mountain soils across various biomes. Its spores can also be found indoors on wooden products, which could explain their presence on bats wing membranes. Chaetomium globosum spores are opportunistic agents of mycosis and neurological infections. However, such illnesses occur at low rates [99]. While another isolated species (C. sphaerospermum) from M. myotis wing membranes is mainly known as a spoilage agent of harvested fruits and vegetables, and it is known as an allergen [100,101].

The next three species (A. ruber, G. aurantiacan and A. quadrifidum) obtained during our research belong to Onygenales order. Nevertheless, only A. quadrifidum (Anamorph synonyms: Trichophyton terrestre) has medical significance because it may be mildly pathogenic for small mammals but not for human. It is a cosmopolitan, geophilic dermatophyte which can be isolated, among others, from soil and bird feathers [102]. In turn, the last two species obtained during our research are P. atrogriseum and P. caricicola. Both species are commonly isolated from plants [56,103].

In our study also two species of Basidiomycota were confirmed on M. myotis wing membranesC. laeve and C. ongulense. Cylindrobasidium and Cystobasidium genera commonly occur in Poland. They may be found on various types of vegetation, especially on broadleaf trees such as maples (Acer spp.), chestnut (Castanea spp.), alder (Alnus spp.), silver birch (Betula pendula), hornbeam (Carpinus betulus), hazel (Corylus spp.), species belonging to Rosaceae family and others. It is far less frequent on coniferous trees however its presence has been confirmed on Scots pine (Pinus sylvestris) [104]. Taking into account habitat preferences and the life cycle of bats, it can be assumed that both of those fungi were probably accidentally obtained from the surface of vegetation or bioaerosols around them in the summer season. It is well known that fungal propagation structures, including those inhabiting plants, can be transported by many animals either internally or externally, including bats [9,105-107]. Additionally, food and shelter availability are the two most important factors determining the quality of habitats used by bats during breeding season [108] both fungal species can be found in woodlands. Therefore, the vast majority of bats in temperate regions rely on forest habitat for at least part of their life cycle [109]. 


\section{Conclusions}

This present study reported the colonization of the wing membranes of female greater mouse-eared bat (M. myotis) during spring emergence from the "Nietoperek" underground hibernation site by fungi. We believe that our study contributes to a better understanding of the fungal community on the wing membranes of bats. Overall, 17 different fungal species were isolated in the study. The species composition was different between individuals. The wing membranes of individual bats were colonized by 4 to 7 fungal species. The most commonly isolated was the cosmopolitan species $P$. chrysogenum. On the other hand, A. jensenii and P. caricicola were rarely cultured, and they inhabited the wing membranes of only one individual. Some fungal species may be pathogens of mammals, including bats. However, Pd was not found. Probably, Pd did not survive the elevated body temperature of already active animals as discussed in previous studies and/or too few bats have been tested. Taking into account habitat preferences and life cycle of bats, it can be assumed that some of fungi were accidentally obtained from the surface of vegetation in the during early spring activity. Bats play important functions in ecosystems, and most of them are threatened with extinction. It can therefore be assumed that monitoring the health status and the microbiome of bats seem to be important aspects for the survival of these mammals. Therefore, in the near future, we want to study the mycobiota of other bat species in order to study the physiological microflora including fungi as they could be part of the normal microbiome and contribute to the health of the wing membrane.

Author Contributions: Conceptualization, methodology, validation, formal analysis, R.O.; investigation, R.O., K.K., M.C., G.A. and T.K.; writing-original draft preparation, R.O., G.A. and T.K.; writing-review and editing, R.O. and T.K.; visualization, R.O.; supervision, R.O.; All authors have read and agreed to the published version of the manuscript.

Funding: This research received no external funding.

Conflicts of Interest: The authors declare no conflicts of interest.

\section{References}

1. Jones, G.; Jacobs, D.S.; Kunz, T.H.; Willig, M.R.; Racey, P.A. CarpeNoctem: The importance of bats as bioindicators. Endanger. Species Res. 2009, 8, 93-115. [CrossRef]

2. Prothero, D.R. The Princeton Field Guide to Prehistoric Mammals; Princeton University Press: Princeton, NJ, USA, 2017; pp. 112-116.

3. Vilas, R.A. Ecological and economical impact of bats on ecosystem. Int. J. Life Sci. 2016, 4, 432-440.

4. Camacho, J.; Heyde, A.; Bhullar, B.-A.S.; Haelewaters, D.; Simmons, N.B.; Abzhanov, A. Peramorphosis, an evolutionary developmental mechanism in neotropical bat skull diversity. Dev. Dynam. 2019, 248, 1129-1143. [CrossRef]

5. Mickleburgh, S.P.; Hutson, A.M.; Racey, P.A. A review of the global conservation status of bats. Oryx 2002, 36, 18-34. [CrossRef]

6. Frick, W.F.; Kingston, T.; Flanders, J. A review of the major threats and challenges to global bat conservation. Ann. N. Y. Acad. Sci. 2020, 1469, 5-25. [CrossRef] [PubMed]

7. Ransome, R.D. The Natural History of Hibernating Bats; Christopher Helm: London, UK, 1990; p. 256.

8. Kokurewicz, T. Sex and age related habitat selection and mass dynamics of Daubenton's bats Myotis daubentonii (Kuhl, 1817) hibernating in natural conditions. Acta Chiropt. 2004, 6, 121-144. [CrossRef]

9. Kokurewicz, T.; Ogórek, R.; Pusz, W.; Matkowski, K. Bats increase the number of cultivable airborne fungi in the "Nietoperek" bat reserve in Western Poland. Microb. Ecol. 2016, 72, 36-48. [CrossRef] [PubMed]

10. Ogórek, R.; Lejman, A.; Matkowski, K. The fungi isolated from the Niedźwiedzia Cave in Kletno (Lower Silesia, Poland). Int. J. Speleol. 2013, 42, 161-166. [CrossRef]

11. Ogórek, R.; Lejman, A.; Matkowski, K. Influence of the external environment on airborne fungi isolated from a cave. Pol. J. Env. Stud. 2014, 23, 435-440.

12. Ogórek, R.; Pusz, W.; Lejman, A.; Uklańska-Pusz, C. Microclimate effects on number and distribution of fungi in the Włodarz undeground complex in the Owl Mountains (Góry Sowie), Poland. J. Cave Karst Stud. 2014, 76, 146-153. [CrossRef] 
13. Vanderwolf, K.J.; Malloch, D.; McAlpine, D.F.; Forbes, G.J. A world review of fungi, yeasts, and slime molds in caves. Int. J. Speleol. 2013, 42, 77-96. [CrossRef]

14. Pusz, W.; Ogórek, R.; Uklańska-Pusz, C.; Zagożdżon, P. Speleomycological research in underground Osówka Complex in Sowie Mountains (Lower Silesia, Poland). Int. J. Speleol. 2014, 43, 27-34. [CrossRef]

15. Szentiványi, T.; Haelewaters, D.; Rádai, Z.; Mizsei, E.; Pfliegler, W.P.; Báthori, F.; Tartally, A.; Christe, P.; Glaizot, O. Climatic effects on the distribution of ant- and bat fly-associated fungal ectoparasites (Ascomycota, Laboulbeniales). Fungal Ecol. 2019, 39, 371-379. [CrossRef]

16. Kirkpatrick, L.; Apoznański, G.; De Bruyn, L.; Gyselings, R.; Kokurewicz, T. Bee markers: A novel method for non-invasive short term marking of bats. Acta Chiropt. 2020, 21, 465-471. [CrossRef]

17. Lundy, M.; Montgomery, I.; Russ, J. Climate change-linked expansion of Nathusius' pipistrelle bat, Pipistrellus nathusii (Keyserling and Blasius 1839). J. Biogeogr. 2010, 37, 2232-2242. [CrossRef]

18. Rebelo, H.; Tarroso, P.; Jones, G. Predicted impact of climate change on European bats in relation to their biogeographic patterns. Glo. Chang. Biol. 2010, 16, 561-576. [CrossRef]

19. Bilgin, R.; Keşişoğlu, A.; Rebelo, H. Distribution Patterns of Bats in the Eastern Mediterranean Region through a Climate Change Perspective. Acta Chiropt. 2012, 14, 425-437.

20. Lorch, J.M.; Muller, L.K.; Russell, R.E.; O'Connor, M.; Lindner, D.L.; Blehert, D.S. Distribution and Environmental Persistence of the Causative Agent of White-Nose Syndrome, Geomyces destructans, in Bat Hibernacula of the Eastern United States. Env. Microbiol. 2013, 79, 1293-1301. [CrossRef]

21. Sherwin, H.A.; Montgomery, W.I.; Lundy, M.G. The impact and implications of climate change for bats. Mamm. Rev. 2013, 43, 171-182. [CrossRef]

22. Winter, R.; Mucedda, M.; Pidinchedda, E.; Kierdorf, U.; Schmidt, S.; Mantilla-Contreras, J. Small in Size But Rich in Bats-Species Diversity and Abandoned Man-Made Structures Put Asinara Island (Sardinia) into Conservation Focus for Bats in the Mediterranean Region. Acta Chiropt. 2007, 19, 119-126. [CrossRef]

23. Martínková, N.; Bačkor, P.; Bartonička, T.; Blažková, P.; Červený, J.; Falteisek, L.; Gaisler, J.; Hanzal, V.; Horáček, D.; Hubálek, Z.; et al. Increasing incidence of Geomyces destructans fungus in bats from the Czech Republic and Slovakia. PLoS ONE 2010, 5, e13853. [CrossRef] [PubMed]

24. Puechmaille, S.J.; Wibbelt, G.; Korn, V.; Fuller, H.; Forget, F.; Mühldorfer, K.; Kurth, A.; Bogdanowicz, W.; Borel, C.; Bosch, T.; et al. Pan European distribution of white-nose syndrome fungus (Geomyces destructans) not associated with mass mortality. PloS ONE 2011, 6, e19167. [CrossRef] [PubMed]

25. Vanderwolf, K.J.; Malloch, D.; McAlpine, D.F. Fungi associated with over-wintering tricolored bats, Perimyotis subflavus, in a white-nose syndrome region of eastern Canada. J. Caves Karst Stud. 2015, 77, 145-151. [CrossRef]

26. McAlpine, D.F.; McBurney, S.; Sabine, M.; Vanderwolf, K.J.; Park, A.Y.; Cai, H. Molecular Detection of Pseudogymnoascus destructans (Ascomycota: Pseudeurotiaceae) and Unidentified Fungal Dermatitides on Big Brown Bats (Eptesicus fuscus) Overwintering inside Buildings in Canada. J. Wildl. Dis. 2016, 52, 902-906. [CrossRef]

27. Visagie, C.M.; Yilmaz, N.; Vanderwolf, K.J.; Renaud, J.B.; Sumarah, M.W.; Houbraken, J.; Assebgui, R.; Seifert, K.A.; Malloch, D. Penicillium diversity in Canadian bat caves, including a new species, P. speluncae. Fungal Syst. Evol. 2020, 5, 1-16. [CrossRef]

28. Hubálek, Z.; Rosický, B.; Otcenásek, M. Fungi from interior organs of free-living small mammals in Czechoslovakia and Yugoslavia. Folia Parasitol. 1980, 27, 269-279.

29. Ogórek, R.; Dyląg, M.; Kozak, B.; Višňovská, Z.; Tančinová, D.; Lejman, A. Fungi isolated and quantified from bat guano and air in Harmanecká and Driny Caves (Slovakia). J. Caves Karst Stud. 2016, 78, 41-49. [CrossRef]

30. Evans, N.J.; Bown, K.; Timofte, D.; Simpson, V.R.; Birtles, R.J. Fatal borreliosis in bat caused by relapsing fever spirochete, United Kingdom. Emerg. Infect. Dis. 2009, 15, 1331-1333. [CrossRef]

31. Mühldorfer, K.; Wibbelt, G.; Haensel, J.; Riehm, J.M.; Speck, S. Yersinia species isolated from bats, Germany. Emerg. Infect. Dis. 2010, 16, 578-580. [CrossRef]

32. Johnson, L.J.A.N.; Miller, A.N.; McCleery, R.A.; McClanahan, R.; Kath, J.A.; Lueschow, S.; Porras-Alfaro, A. Psychrophilic and psychrotolerant fungi on bats and the presence of Geomyces spp. on bat wings prior to the arrival of white nose syndrome. Appl. Environ. Microbiol. 2013, 79, 5465-5471. [CrossRef] 
33. Vanderwolf, K.J.; Forbes, G.J.; Malloch, D.; McAlpine, D.F. Ectomycota Associated with Hibernating Bats in Eastern Canadian Caves prior to the Emergence of White-Nose Syndrome. Northeast. Nat. 2013, 20, 115-130. [CrossRef]

34. Malloch, D.; Sigler, L.; Hambleton, S.; Vanderwolf, K.J.; Gibas, C.F.C.; McAlpine, D.F. Fungi associated with hibernating bats in New Brunswick caves: The genus Leuconeurospora. Botany 2016, 94, 1171-1181. [CrossRef]

35. Wibbelt, G.; Kurth, A.; Hellmann, D.; Weishaar, M.; Barlow, A.; Veith, M.; Prüger, J.; Görföl, T.; Grosche, L.; Bontadina, F.; et al. White-nose syndrome fungus (Geomyces destructans) in bats, Europe. Emerg. Infect. Dis. 2010, 16, 1237-1243. [CrossRef] [PubMed]

36. Turner, G.G.; Reeder, D.M. Update of white-nose syndrome in bats. Bat Res. News 2009, 50, 47-53.

37. Frick, W.F.; Pollock, J.F.; Hicks, A.C.; Langwig, K.E.; Reynolds, D.S.; Turner, G.G.; Butchkoski, C.M.; Kunz, T.H. An emerging disease causes regional population collapse of a common North American bat species. Science 2010, 329, 679-682. [CrossRef] [PubMed]

38. Langwig, K.E.; Frick, W.F.; Bried, J.T.; Hicks, A.C.; Kunz, T.H. Sociality, densitydependence and microclimates determine the persistence of populations suffering from a novel fungal disease, white-nose syndrome. Ecol. Lett. 2012, 15, 1050-1057. [CrossRef]

39. Puechmaille, S.J.; Verdeyroux, P.; Fuller, H.; Gouilh, M.A.; Bekaert, M.; Teeling, E.C. White-nose syndrome fungus (Geomyces destructans) in Bat, France. Emerg. Infect. Dis. 2010, 16, 290-293. [CrossRef]

40. Pikula, J.; Bandouchova, H.; Novotny, L.; Meteyer, C.U.; Zukal, J.; Irwin, N.R.; Zima, J.; Martínková, N. Histopathology confirms white-nose syndrome in bats in Europe. J. Wildl. Dis. 2012, 48, 207-211. [CrossRef]

41. Garzoli, L.; Riccucci, M.; Patriarca, E.; Debernardi, P.; Boggero, A.; Pecoraro, L.; Picco, A.M. First isolation of Pseudogymnoascus destructans, the fungal causative agent of white-nose disease, in bats from Italy. Mycopathologia 2019. [CrossRef]

42. Kokurewicz, T.; Apoznański, G.; Gyselings, R.; Kirkpatrick, L.; De Bruyn, L.; Haddow, J.; Glover, A.; Schofield, H.; Schmidt, C.; Bongers, F.; et al. 45 years of bat study and conservation in Nietoperek bat reserve (Western Poland). Nyctalus (N.F.) 2019, 19, 252-269.

43. Ogórek, R.; Guz-Regner, K.; Kokurewicz, T.; Baraniok, E.; Kozak, B. Airborne bacteria cultivated from underground hibernation sites in the Nietoperek bat reserve (Poland). J. Cave Karst Stud. 2018, 80, 161-171. [CrossRef]

44. Dietz, C.; von Helversen, O. Illustrated Identification Key to the Bats of Europe. Tech. Rep. $2004,72$. [CrossRef]

45. Rogowska, K.; Kokurewicz, T. The longest migrations of three bat species to the "Nietoperek" bat reserve (western Poland). Ber. Nat. Ges. Oberlausitz 2007, 15, 53-60.

46. Kuehn, H.H.; Orr, G.F. Arachniotus ruber (Van Tieghem) Schroeter. Trans. Br. Mycol. Soc. 1964, 47, 553-558. [CrossRef]

47. Orr, G.F.; Ghosh, G.R.; Roy, K. The Genera Gymnascella, Arachniotus, and Pseudoarachniotus. Mycologia 1977, 69, 126-163. [CrossRef]

48. Weitzman, I.; Summerbell, R.C. The Dermatophytes. Clin. Microbiol. Rev. 1995, 8, 240-259. [CrossRef] [PubMed]

49. Wang, L.; Zhuang, W.-Y. Penicillium brevistipitatum, a new species isolated from Jilin Province, China. Mycotaxon 2005, 93, 233-240.

50. Bensch, K.; Braun, U.; Groenewald, J.Z.; Crous, P.W. The genus Cladosporium. Stud. Mycol. 2012, 72, 1-401. [CrossRef]

51. Jurjević, Ž.; Peterson, S.W.; Horn, B.W. Aspergillus section Versicolores: Nine new species and multilocus DNA sequence based phylogeny. IMA Fungus 2012, 3, 59-79. [CrossRef]

52. Perdomo, H.; García, D.; Gené, J.; Cano, J.; Sutton, D.A.; Summerbell, R.; Guarro, J. Phialemoniopsis, a new genus of Sordariomycetes, and new species of Phialemonium and Lecythophora. Mycologia 2013, 105, 398-421. [CrossRef]

53. Sandoval-Denis, M.; Gené, J.; Sutton, D.A.; Cano-Lira, J.F.; de Hoog, G.S.; Decock, C.A.; Wiederhold, N.P.; Guarro, J. Redefining Microascus, Scopulariopsis and allied genera. Persoonia 2016, 36, 1-36. [CrossRef] [PubMed] 
54. Wang, X.W.; Lombard, L.; Groenewald, J.Z.; Li, J.; Videira, S.I.R.; Samson, R.A.; Liu, X.Z.; Crous, P.W. Phylogenetic reassessment of the Chaetomium globosum species complex. Persoonia 2016, 36, 83-133. [CrossRef] [PubMed]

55. de Hoog, G.S.; Dukik, K.; Monod, M.; Packeu, A.; Stubbe, D.; Hendrickx, M.; Kupsch, C.; Stielow, J.B.; Freeke, J.; Göker, M.; et al. Toward a novel multilocus phylogenetic taxonomy for the dermatophytes. Mycopathologia 2017, 182, 5-31. [CrossRef] [PubMed]

56. Crous, P.W.; Luangsa-ard, J.J.; Wingfield, M.J.; Carnegie, A.J.; Hernández-Restrepo, M.; Lombard, L.; Roux, J.; Barreto, R.W.; Baseia, I.G.; Cano-Lira, J.F.; et al. Fungal Planet description sheets: 785-867. Persoonia 2018, 41, 238-417. [CrossRef] [PubMed]

57. Ogórek, R.; Kurczaba, K.; Łobas, Z.; Żołubak, E.; Jakubska-Busse, A. Species Diversity of Micromycetes Associated with Epipactis helleborine and Epipactis purpurata (Orchidaceae, Neottieae) in Southwestern Poland. Diversity 2020, 12, 182. [CrossRef]

58. Dylag, M.; Sawicki, A.; Ogórek, R. Diversity of Species and Susceptibility Phenotypes toward Commercially Available Fungicides of Cultivable Fungi Colonizing Bones of Ursus spelaeus on Display in Niedźwiedzia Cave (Kletno, Poland). Diversity 2019, 11, 224. [CrossRef]

59. White, T.J.; Bruns, T.; Lee, S.; Taylor, J.W. Amplification and direct sequencing of fungal ribosomal RNA genes for phylogenetics. In PCR Protocols: A Guide to Methods and Applications; Innis, M.A., Gelfand, D.H., Sninsky, J.J., White, T.J., Eds.; Academic Press: New York, NY, USA, 1990; pp. 315-322.

60. Ogórek, R.; Dylag, M.; Kozak, B. Dark stains on rock surfaces in Driny Cave (Little Carpathian Mountains, Slovakia). Extremophiles 2016, 20, 641-652. [CrossRef]

61. Ogórek, R.; Pusz, W.; Zagożdżon, P.P.; Kozak, B.; Bujak, H. Abundance and diversity of psychrotolerant cultivable mycobiota in winter of a former aluminous shale mine. Geomicrobiol. J. 2017, 34, 823-833. [CrossRef]

62. Zukal, J.; Bandouchova, H.; Bartonicka, T.; Berkova, H.; Brack, V.; Brichta, J.; Dolinay, M.; Jaron, K.S.; Kovacova, V.; Kovarik, M.; et al. White-nose Syndrome fungus: A generalist pathogen of hibernating bats. PLoS ONE 2014, 9, e97224. [CrossRef]

63. Zukal, J.; Bandouchova, H.; Brichta, J.; Cmokova, A.; Jaron, K.S.; Kolarik, M.; Kovacova, V.; Kubátová, A.; Nováková, A.; Orlov, O.; et al. White-nose syndrome without borders: Pseudogymnoascus destructans infection tolerated in Europe and Palearctic Asia but not in North America. Sci. Rep. 2016, 6, 19829. [CrossRef]

64. Morita, R.Y. Psychrophilic bacteria. Bacteriol. Rev. 1975, 39, 144-167. [CrossRef] [PubMed]

65. Wynn-Williams, D.W. Ecological aspects of Antarctic microbiology. Adv. Microb. Ecol. 1990, 11, 71-146.

66. Aislabie, J.M.; Balks, M.R.; Foght, J.M.; Waterhouse, E.J. Hydrocarbonspills on Antarctic soils: Effects and Management. Environ. Sci. Technol. 2004, 38, 1265-1274. [CrossRef]

67. Zukal, J.; Berková, H.; Madaraszová, J. Flying or sleeping: Flight activity of bats in natural cave with confirmed WNS. J. Vertebr. Biol. 2016, 65, 46-51. [CrossRef]

68. Dominguez-Villar, D.; Lojen, S.; Krklec, K.; Baker, A.; Fairchild, I.J. Is global warming affecting cave temperatures? Experimental and model data from aparadigmatic case study. Clim. Dyn. 2015, 45, 569-581. [CrossRef]

69. Nadkarni, N.M.; Solano, R. Potential effects of climate change on canopy communities in a tropical cloud forest: An experimental approach. Oecologia 2002, 131, 580-586. [CrossRef]

70. Garcia-Solache, M.A.; Casadevall, A. Global warming will bring new fungal diseases for mammals. Am. Soc. Microbiol. 2010, 1, 1-3. [CrossRef]

71. Puechmaille, S.J.; Frick, W.F.; Kunz, T.H.; Racey, P.A.; Voigt, C.C.; Wibbelt, G.; Teeling, E.C. White-nose Syndrome: Is this emerging disease a threat to European bats? Trends Ecol. Evol. 2011, 26, 570-576. [CrossRef]

72. Ogórek, R.; Kalinowska, K.; Pląskowska, E.; Baran, E.; Moszczyńska, E. Zanieczyszczenia powietrza grzybami na różnych podłożach hodowlanych w wybranych pomieszczeniach kliniki dermatologicznej. Część 1. Mikol. Lek. 2011, 18, 30-38. (In Polish)

73. Litman, M.L. A culture medium for the primary isolation of fungi. Science 1947, 106, 109-111. [CrossRef]

74. Verant, M.L.; Boyles, J.G.; Waldrep, W., Jr.; Wibbelt, G.; Blehert, D.S. Temperature-dependent growth of Geomyces destructans, the fungus that causes bat white-nose syndrome. PLoS ONE 2012, 7, e46280. [CrossRef] [PubMed] 
75. Ruben, J. The evolution of endothermy in mammals and birds-From physiology to fossils. Ann. Rev. Physiol. 1995, 57, 69-95. [CrossRef] [PubMed]

76. Pikula, J.; Amelon, S.K.; Bandouchova, H.; Bartonička, T.; Berkova, H.; Brichta, J.; Hooper, S.; Kokurewicz, T.; Kolarik, M.; Köllner, B.; et al. White-nose syndrome pathology grading in Nearctic and Palearctic bats. PLoS ONE 2017, 12, e0180435. [CrossRef] [PubMed]

77. Bandouchova, H.; Bartonička, T.; Berkova, H.; Brichta, J.; Kokurewicz, T.; Kovacova, V.; Linhart, P.; Piacek, V.; Pikula, J.; Zahradníková, A., Jr.; et al. Alterations in the health of hibernating bats under pathogen pressure. Sci. Rep. 2018, 8, 6067. [CrossRef] [PubMed]

78. Martínková, N.; Pikula, J.; Zukal, J.; Kovacova, V.; Bandouchova, H.; Bartonička, T.; Botvinkin, A.D.; Brichta, J.; Dundarova, H.; Kokurewicz, T.; et al. Hibernation temperature-dependent Pseudogymnoascus destructans infection intensity in Palearctic bats. Virulence 2018, 9, 1734-1750. [CrossRef]

79. Hoyt, J.R.; Langwig, K.E.; Okoniewski, J.; Frick, W.F.; Stone, W.B.; Kilpatrick, A.M. Long-Term Persistence of Pseudogymnoascus destructans, the Causative Agent of White-Nose Syndrome, in the Absence of Bats. EcoHealth 2014, 12, 330-333. [CrossRef]

80. Campbell, L.J.; Walsh, D.P.; Blehert, D.S.; Lorch, J.M. Long-term survival of Pseudogymnoascuc destructans at elevated temperatures. J. Wildl. Dis. 2020, 56, 278-287. [CrossRef]

81. Carpenter, R.E. Flight physiology of intermediate-sized fruit bats (Pteropodidae). J. Exp. Biol. 1986, 120, 79-103.

82. Thomas, S.P.; Suthers, R.A. The physiology and energetics of bat flight. J. Exp. Biol. 1972, 57, 317-335.

83. Rozporządzenie Ministra Środowiska z dnia 6 Października 2014 r. w Sprawie Ochrony Gatunkowej Zwierząt (Dz.U. z 2014 r. poz. 1348). Available online: http://isap.sejm.gov.pl/isap.nsf/DocDetails.xsp?id= WDU20140001348 (accessed on 10 April 2020).

84. Furmankiewicz, J.; Zając, K. Ochrona największej na Dolnym Śląsku kolonii rozrodczej nocka dużego Myotis myotis (BORKHAUSEN 1797). Przyroda Sudetów Zachodnich 1999, 2, 89-92.

85. Gas, A.; Postawa, T. Bat fauna of the Studnisko Cave. Studia Chiropterol. 2001, 2, 3-16.

86. Łupicki, D.; Cichocki, J. Występowanie nietoperzy na terenie Międzyrzeckiego Rejonu Umocnionego w okresie letnim. Nietoperze 2008, 9, 19-27.

87. Pekkanen, J.; Hyvarinen, A.; Haverinen-Shaughnessy, U.; Korppi, M.; Putus, T.; Nevalainen, A. Moisture damage and child-hood asthma: A population-based incident case-control study. Eur. Respir. J. 2007, 29, 509-515. [CrossRef] [PubMed]

88. Geltner, C.; Lass-Flör, C.; Bonatti, H.; Müller, L.; Stelzmüller, I. Invasive Pulmonary Mycosis Due to Penicillium chrysogenum: A New Invasive Pathogen. Transplantation 2013, 95, 21-23. [CrossRef]

89. Garber, G. An overview of fungal infections. Drugs 2001, 61, 1-12. [CrossRef]

90. Gautier, M.; Normand, A.-C.; Ranque, S. Previously unknown species of Aspergillus. Clin. Microbiol. Infect. 2016, 22, 662-669. [CrossRef]

91. Elad, D.; Segal, E. Diagnostic Aspects of Veterinary and Human Aspergillosis. Front. Microbiol. 2018, 9, 1303. [CrossRef]

92. Rhodes, J.C.; Jensen, H.E.; Nillius, A.M. Aspergillus and aspergillosis. J. Med. Vet. Mycol. 1992, 30, 51-57. [CrossRef]

93. Anbu, P.; Gopinath, S.C.B.; Hilda, A.; Lakshmipriya, T.; Annadurai, G. Optimization of extracellular keratinase production by poultry farm isolate Scopulariopsis brevicaulis. Bioresour. Technol. 2007, 98, 1298-1303. [CrossRef]

94. Skóra, M.; Bielecki, J.; Bulanda, M.; Macura, A.B.; Jagielski, T. Grzyby z rodzaju scopulariopsis-mało znane patogeny człowieka. Post. Mikrobiol. 2015, 54, 44-52.

95. Tejesvi, M.V.; Tamhankar, S.A.; Kini, K.R.; Rao, V.S.; Prakash, H.S. Phylogenetic analysis of endophytic Pestalotiopsis species from ethnopharmaceutically important medicinal trees. Fungal Divers. 2009, 38, 167-183.

96. Wang, Y.; Jin, L.; Lin, L.; Zhu, T.T.; Chen, X.-R.; Chao, L.-P. New hosts for Bartalinia and Chaetopyrena in China. Mycotaxon 2016, 131, 1-6. [CrossRef]

97. Nguyen, T.T.T.; Lee, S.H.; Jeon, S.J.; Lee, H.B. First Records of Rare Ascomycete Fungi, Acrostalagmus luteoalbus, Bartalinia robillardoides, and Collariella carteri from Freshwater Samples in Korea. Mycobiology 2019, 47, 1-11. [PubMed] 
98. Gangadevi, V.; Muthumary, J. Taxol, an anticancer drug produced by an endophytic fungus Bartalinia robillardoides Tassi, isolated from a medicinal plant, Aegle marmelos Correa ex Roxb. World J. Microbiol. Biotechnol. 2008, 24, 717-724.

99. Provost, N.; Shi, C.; She, Y.; Cyr, T.; Miller, D. Characterization of an antigenic chitosanase from the cellulolytic fungus Chaetomium globosum. Med. Mycol. 2013, 51, 290-299.

100. Hocking, A.D.; Miscamble, B.F.; Pitt, J.I. Water relations of Alternaria alternata, Cladosporium cladosporioides, Cladosporium sphaerospermum, Curvularia lunata and Curvularia pallescens. Mycol. Res. 1994, 98, 91-94. [CrossRef]

101. Zalar, P.; de Hoog, G.S.; Schroers, H.-J.; Crous, P.W.; Groenewald, J.Z.; Gunde-Cimerman, N. Phylogeny and ecology of the ubiquitous saprobe Cladosporium sphaerospermum, with descriptions of seven new species from hypersaline environments. Stud. Mycol. 2007, 58, 157-183. [CrossRef]

102. English, M.P. The ecology of some keratinophilic fungi associated with hedge-hogs. N. Z. Med. J. 1964, 63, 586-591.

103. Read, R.W.; Chuck, R.S.; Rao, N.A.; Smith, R.E. Traumatic Acremonium atrogriseum keratitis following laser-assisted in situ keratomileusis. Arch. Ophthalmol. 2000, 118, 418-421.

104. Wojewoda, W. Checklist of Polish Larger Basidiomycetes. Krytyczna Lista Wielkoowocnikowych Grzybów Podstawkowych Polski; W. Szafer Institute of Botany-Polish Academy of Sciences: Kraków, Polska, 2003.

105. Holz, P.H.; Lumsden, L.F.; Marenda, M.S.; Browning, G.F.; Hufschmid, J. Two subspecies of bent-winged bats (Miniopterus orianae bassanii and oceanensis) in southern Australia have diverse fungal skin flora but not Pseudogymnoascus destructans. PLoS ONE 2018, 13, e0204282.

106. Vašutová, M.; Mleczko, P.; López-García, A.; Maček, I.; Boros, G.; Ševčík, J.; Fujii, S.; Hackenberger, D.; Tuf, I.H.; Hornung, E.; et al. Taxi drivers: The role of animals in transporting mycorrhizal fungi. Mycorrhiza 2019, 29, 413-434. [CrossRef] [PubMed]

107. Golan, J.J.; Pringle, A. Long-distance dispersal of fungi. Fungal Kingd. 2017, 5, 309-333.

108. Dietz, C.; Nill, D.; von Helversen, O. Bats of Britain, Europe and Northwest Africa; A \&C Black: London, UK, 2009; p. 400.

109. Altringham, J.D. Bats: From Evolution to Conservation; Oxford University Press: Oxford, UK, 2013.

(C) 2020 by the authors. Licensee MDPI, Basel, Switzerland. This article is an open access article distributed under the terms and conditions of the Creative Commons Attribution (CC BY) license (http://creativecommons.org/licenses/by/4.0/). 